\title{
The Financial Bootstrapping Methods Employed by New Micro Enterprises in the Retail Sector in South Africa
}

\author{
Olawale Fatoki \\ Department of Business Management, Turfloop Campus, \\ University of Limpopo, Limpopo Province, South Africa \\ Email: Olawale.fatoki@ul.ac.za
}

Doi:10.5901/mjss.2014.v5n3p72

\begin{abstract}
New micro-enterprises in the retail sector are vital to the growth of the South African economy. Inaccessibility to formal debt and equity markets is one of the primary causes of the failure of new micro-enterprises in South Africa. Innovative financing methods are vital to the survival of new micro-enterprises in South Africa. This study investigates the financial bootstrapping methods employed by new micro-enterprises in the retail sector in South Africa. Data was collected through the use of selfadministered questionnaires in a survey. Descriptive statistics and factor analysis were used for data analysis. Factor analysis identified four bootstrapping methods from twenty nine question items. These are owners' resources, accounts receivable management, sharing resources and delaying payments. Recommendations to improve financial bootstrapping by microenterprises are suggested.
\end{abstract}

Keywords: Financial bootstrapping, new micro-enterprises, retail sector, South Africa

\section{Introduction}

South Africa suffers from high rate of unemployment with an official unemployment rate of estimate of $24.7 \%$ (Statistics South Africa, 2013). Micro-enterprises (a part of the broad small medium and micro enterprises sector (SMMEs)) are expected to be an important vehicle to address the challenges of job creation, sustainable economic growth, equitable distribution of income and the overall stimulation of economic development in South Africa (FinMark Trust, 2006). According to Rolfe et al. (2010), micro-enterprises are the most pervasive entrepreneurial activity in South Africa. 70\% of the micro- enterprises are in the retail and commerce sectors. Gauteng Province Provincial Treasury (2012) points out that the retail industry in South Africa has grown considerably over the past few years with important contributions to employment and economic growth.

Despite the highlighted contributions of micro-enterprises in the retail sector in South Africa, these enterprises suffer from a high failure rate. Van Scheers (2010) in a study of small groceries shops (mainly micro-enterprises) in South Africa points out that the failure rate of micro- enterprises in the retail sector is between $70 \%$ and $80 \%$. In addition, the vast majority of retail micro-enterprises that fail are the new ones. Von Broembsen et al. (2005) state that the probability of a new small business surviving beyond 42 months and becoming an established firm is less likely in South Africa than in any other Global Entrepreneurship Monitor (GEM) sampled country. Adcorp (2012) reveals that around 440,000 micro and small enterprises (including those in the retail sector) have closed in the last five years in South Africa. Various challenges cause the high failure rate of micro enterprises in the retail sector in South Africa. One of them is inaccessibility to the external finance. According to Maas and Herrington (2006) and Herrington et al. (2009), access to finance is a major problem for the South African entrepreneur. A lack of financial support is the second most reported contributor to the failure of micro and small enterprises after education and training in South Africa. The majority of microenterprises in South Africa do not have access to formal debt or equity markets (Arko-Achemfour, 2012).

Winborg (2008) points out that financial bootstrapping is used by firms when internal or external finance is not available. Firms without access to formal debt or equity markets can creatively access resources through different means. Innovative financing methods are vital to the survival of new micro enterprises in the retail sector. Barringer and Ireland (2010) note that bootstrapping involves finding creative ways to avoid the need for external finance through creativity, ingenuity, thriftiness and cost-cutting. Cornwall (2010) and Fatoki (2013) add that bootstrapping is about creating the desired impact using only resources that are necessary to achieve the desired outcomes. Therefore, bootstrapping can be one of the ways to improve access to resources and the survival rate by new micro-enterprises in the retail sector in South Africa. 


\section{The Objective of the Study}

The sustainability of new micro-enterprises in the retail is vital to the economic prosperity of South Africa (Ntema and Marais, 2012). One of the causes of the failure of new micro- enterprises in the retail sector is inaccessibility to conventional external debt and equity finance (Rolfe et al. 2010). Thus, innovative approaches to financing (bootstrapping) are needed for new micro-enterprises in the retail sector to survive and grow. The objective of this study is to investigate empirically the bootstrapping strategies employed by new micro-enterprises in the retail sector in South Africa. The results of this study can yield some interesting insights on the non-conventional methods of financing by new micro-enterprises in the retail sector.

\section{Literature Review}

\subsection{Resource dependency theory}

According to Pfeffer and Salancik (1978), RBT (Resource Dependency Theory) argues that resources are a critical or important part of an organisation's operation. Kraaijenbrink et al. (2010) point out that resources can help a new firm to gain and sustain competitive advantage. Elsenhardt and Martin (2000) use the RBT to demonstrate the financing needs of new small firms. These firms need resources such as fixed assets and working capital to be able to achieve a competitive advantage in the market. According to Bolingtoft et al. (2003), to establish and sustain a new small firm, the entrepreneur needs to have access to different types of resources (i) human capital; (ii) physical capital; and (iii) financial capital, each playing different, but equally important roles during the life cycle of the firm. Bolingtoft et al. (2003) further point out that there are many explanations offered for the failure of small firms. One of the most frequently cited reasons is resource poverty. This is consistent with the view of Timmons and Spinelli (2007) that the decision on what resources are needed, when they are needed and how to acquire them are strategic decisions that fit with other driving forces of entrepreneurship. According to Ebben and Johnson (2006), the traditional view of bootstrapping coincides with the RBT as expoused by Pfeffer and Salancik in 1978. RBT assumes that the owners of new firms do not possess all of the financial resources that they need and must therefore obtain external finance.

\section{Capital structure theories and financial bootstrapping}

Capital structure is described as the mix of debt and equity that a firm uses to finance its operations (Gitman, 2003). According to Demirguc-Kunt et al. (2006), the two primary sources of external finance for new micro-enterprises are equity and debt. Blumberg and Letterie (2008) point out that external equity in the form of venture capital or the stock exchange is usually not available for new micro enterprises. Venture capitalists often enter the firm at the middle or later stages of its life cycle. According to the South African Venture Capital Association (2008) there are at least 65 venture capital funds in South Africa controlling a total of R29 billion with an average investment size of R15.4 million. However, new venture investment with a focus on small firms is approximately R1.1 billion which is only $3.8 \%$ of the funds. The lack of venture capital funds makes new micro-enterprises dependent on debt finance. Despite the dependence of new micro-enterprises on debt finance, paradoxically access to debt finance is very limited these firms. Commercial banks often hesitate to lend to mew micro-enterprises leading to inaccessibility to debt finance (Rogerson, 2008).

Theories on inaccessibility to external finance by new micro-enterprises include the Agency theory by Jensen and Meckling (1976) and the Pecking Order theory (POT) by Myers (1984). According to Jensen and Meckling (1976), agency problems such as asymmetric information and moral hazards can impact on the availability of credit to new micro enterprises. Myers (1984) argues that management has a preference to choose internal financing before external financing. When a firm is forced to use external financing sources, managers select the least risky and demanding source first. When it is necessary to issue external sources, debt issuance is preferred to new equity. POT postulates that the cost of financing increases with asymmetric information. This can negatively impact on the ability of new micro enterprises to raise external finance. Stiglitz and Weiss (1981) agree that agency problems such as asymmetric information and moral hazards can impact on the availability of credit and hence the capital structure of new microenterprises. Thus, owners of new micro- enterprises tend to seek funding through various non-traditional financial bootstrapping methods.

Winborg and Landström (2001) and Ebben and Johnson (2006) define financial bootstrapping as the use of resourceful and innovative methods, which (i) minimize the amount of finance firms need to raise through financial 
market transactions with traditional outside financiers and (ii) allow firms to secure resources owned by others at little or no cost. According to Vanacker et al. (2011), financial bootstrapping is a resource dependence management strategy. Consistent with the RDT framework, firm owners take actions to reduce financial uncertainty and dependence of their business by actively deploying bootstrapping techniques. Bootstrap financing refers to a range of highly creative ways of acquiring resources without borrowing money or raising equity from traditional sources (Ebben and Johnson, 2006; Yilmazer and Schrank, 2006; Tomory, 2011).

Vanacker et al. (2011) further adds that the literature has offered contradictory views on the value of financial bootstrapping for venture development. Bootstrap strategies may allow young ventures to pursue new opportunities without owning a sizeable resource base and without mobilizing a large amount of outside finance to buy more resources. In addition, there can be a problem of diminished flexibility. This is often one of the consequences of premature funding. Too much initial funding can lead to problems with outside investors. Roberts (2003) notes that bootstrapping teaches the entrepreneur to be frugal with resources. Fiscal discipline is built in a bootstrap environment. Baker and Nelson (2005) point out that firms survive and even flourish, solving problems and exploiting opportunities despite resource constraints. Hence, bootstrap strategies may positively influence the level of value added and growth in value added across time. Brush (2008) argues that successful entrepreneurs must master three key strategies: (1) develop a clear vision (2) manage cash creatively, or learn to bootstrap and (3) be able to persuade others to commit to the venture using social skills. Bootstrap financing, however, can offer owners of small firms a source of capital that improves liquidity and strengthens cash flow. Winborg and Landstrom (2001) and Vanacker et al. (2011) point out that one of the disadvantages associated with bootstrapping is the lack of ownership of resources. This can lead to a certain level of insecurity.

According to Vanacker et al. (2011) bootstrap strategies include the use of owner-related finance, minimization of accounts receivable, sharing and borrowing of resources, delaying payments, minimization of capital invested and using subsidy finance There are four types of bootstrapping options (i.e., bootstrapping product development, bootstrapping business development, bootstrapping to minimize the need for (outside) capital financing, and bootstrapping to minimize the need for capital). Lahm and Little (2005) add that bootstrapping strategies include (1) the acquisition and control of resources (both tangible and intangible) and (2) the efficient (minimising) uses of those resources to finance the enterprise for growth. These two methods form the basis for an overall strategy. A bootstrapping entrepreneur's very survival may well depend on his or her ability to be highly adaptable and operate on a shoestring budget. Winborg and Landstrom (2001) identify thirty two bootstrapping strategies. Cluster analysis identified six bootstrapping strategies. (1) delaying bootstrapping (2) relationship-oriented bootstrapping (3) subsidy-oriented bootstrapping (4) minimising bootstrapping (5) non-bootstrapping and (6) private owner-financed bootstrapping A similar study by Schinck and Sarkar (2012) also identified four bootstrapping strategies. (1) acquisition of subsidies and investors (2) internal management process ( 3 delaying cost, and (4) minimising investment.

\section{Research Methodology}

The survey was conducted in Polokwane, Mankweng and Seshego in the Limpopo province of South Africa. The empirical approach consists of data collection through the use of self-administered questionnaire in a survey. According to the Parliament of the Republic of South Africa (1995), a micro-enterprise is a business with (1) total full-time equivalent of paid employee of less than 5 (2) total annual turnover of less than R150,000 and (3) total gross asset value (fixed property excluded) of less than R100,000. Maas and Herrington (2006) observe that the creation of a new small firm is a two-stage process. The first phase is the start-up phase, a three month period during which individuals identify the products or services that the firm will trade in, access resources and put in place the necessary infrastructure such as staff. The next phase, a period of 3-42 months, is when the small firm begins to trade and compete with other firms in the market place. Therefore, a new micro- enterprise can be described as a business that has been in existence for a period not longer than forty- two months. Once a firm has successfully existed for more than 42 months, it becomes an established firm. The focus of the study is on new micro-enterprises in the retail sector. These are enterprises that have been in existence for 42 months or less and employ less than five employees.

Because of the difficulty in obtaining the population of micro-enterprises in the study area, convenience sampling and the snowball sampling methods were used. According to Cooper and Schindler (2008), convenience sampling is a non-probability sampling technique where subjects are selected because of their convenient accessibility and proximity to the researcher. Snowball sampling method is a non-probability sampling technique where existing study subjects recruit future subjects from among their acquaintances. The use of convenience sampling is consistent with previous empirical 
studies on micro and small enterprises in South Africa such as Farrington and Matchaba-Hove (2011) and ArkoAchemfuor (2012).

A pilot study was conducted on the survey instrument used in this research with twelve owners of new microenterprises in the retail sector in order to ensure face and content validity. The pilot study led to some modifications to the questionnaire. Owners were assured of confidentiality with regard to the data collected. Data collection was done with the assistance of two trained field agents. The questionnaires were given to the owners of the micro-enterprises to complete. The questionnaire was divided into four parts (1) biographical information (2) need for external finance (3) access to external finance (4) financial bootstrapping methods employed. Question items included dichotomous questions and Likert scale questions. The part of the questionnaire on financial bootstrapping was adapted from Winborg and Landstrom (2001) and Schinck and Sarkar (2012). The questionnaire contained twenty nine question items. 19 Likert scale questions where the respondents could answer 1-5 representing "1 never use", "2 rarely use", "3occassionally", "4 a moderate amount" " 5 a great deal" The questionnaire also includes 10 non-metric dummy variable questions where the respondents could answer yes or no. The aim is to discover financial bootstrapping methods used at least once and those that have never been used by new micro-enterprises. The Cronbach's alpha was used to measure reliability. Data analysis included univariate analysis and the principal component analysis.

\section{Research Results}

\subsection{Response rate and Biographical information}

156 questionnaires were distributed to the owners of new micro-enterprises in the retail stores in the study area and 75 questionnaires were returned after repeated phone calls and visits. The response rate was $47.8 \% .73$ respondents were sole proprietors and two partnerships. 44 were males and 21 females. 44 respondents have post-matric qualifications, 31 respondents have Matric or below. 5 respondents have no employee, 22 have one employee, 25 have two employees and 20 three employees and 3 have four employees.

\subsection{Need for external debt capital:}

Out of 75 respondents, 63 respondents are in need of external capital and 12 respondents do not need external capital. It can be concluded that most of the respondents are in need of external capital. Zhou and Chen (2008) identify that SMMEs need financial resources to take advantage of business opportunities. According to Bolingtoft et al. (2003) and Winton and Yerramilli (2008), to establish and sustain a new SMME, the entrepreneur needs to have access to different types of resources (i) human capital; (ii) physical capital; and (iii) financial capital, each playing different, but equally important roles during the life cycle of a new SMME. Atieno (2009) observe that access to external finance is needed to reduce the impact of cash flow problems for SMMEs. Financing is needed for new micro-enterprises to start and expand operations, develop new products, invest in new staff or production facilities. Carpenter and Petersen (2002) investigate the relationship between dependence on internal finance and the growth of new SMMEs. They find that growth of new SMMEs is constrained by dependence on internal finance. In contrast, enterprises that make use of external funds exhibit growth rates far above what can be supported by internal finance. Therefore new micro-enterprises in the retail sector need capital from external sources.

\subsection{Access to external debt capital}

Out of the 63 respondents in need of external debt capital, 35 applied for debt capital and 28 did not apply. Unwillingness to apply for external debt capital by the owners of new micro enterprises suggests a level of discouragement. Kon and Storey (2001), in the discouraged borrowers' theory define discouraged borrowers as good borrowers who do not apply for a bank loan because they feel they will be rejected. Out of the 25 that applied, 6 (24\%) obtained credit from commercial banks. Beck (2007) finds that new SMMEs in developing countries often report a widespread shortage of external finance. This is termed the "finance gap". 


\subsection{Bootstrapping strategies}

Table 1: financial bootstrapping methods used by new micro enterprises in the retail sector

\begin{tabular}{|l|c|c|}
\hline & Number & Percentage \\
\hline Withhold owner's/manager's salary for some time & 62 & $83 \%$ \\
\hline Share premises with other business & 61 & $81 \%$ \\
\hline Buys on consignment from suppliers & 61 & $81 \%$ \\
\hline Obtain loans and contributions from family and friends & 60 & 80 \\
\hline Minimise inventory & 58 & $77 \%$ \\
\hline Seeks out the best conditions possible with suppliers & 58 & $77 \%$ \\
\hline Deliberately delay payments to suppliers & 56 & $75 \%$ \\
\hline Offers customers discounts if paying in cash, in order to get paid earlier & 56 & $75 \%$ \\
\hline Deliberately chooses customers who pay quickly & 52 & $69 \%$ \\
\hline Occasionally hires personnel for a shorter period instead of employing permanently & 52 & $69 \%$ \\
\hline Contributes capital via other projects the owner gets paid in & 50 & $67 \%$ \\
\hline Gets payments in advance from customers & 40 & $53 \%$ \\
\hline Uses managers private credit card for business expense & 38 & $51 \%$ \\
\hline Gives the same terms of payment to all customers & 34 & $45 \%$ \\
\hline Buys used equipment instead of new & 35 & $47 \%$ \\
\hline Coordinates purchases together with other businesses (for better agreements) & 27 & $36 \%$ \\
\hline Employs relatives and or friends at non-market salary & 21 & $28 \%$ \\
\hline On any occasion liquidated a business relation with a customer for frequently paying late & 21 & $28 \%$ \\
\hline Uses routines in order to speed up invoicing & 20 & $27 \%$ \\
\hline Borrows equipment or machinery from other businesses & 20 & $27 \%$ \\
\hline Shares equipment with other businesses & 20 & $27 \%$ \\
\hline Runs the business completely in the home & 6 & $8 \%$ \\
\hline Carries out barter instead of buying products/services & 2 & $3 \%$ \\
\hline Shares employees with other businesses & 0 & $0 \%$ \\
\hline Leases equipment from leasing businesses & 0 & $0 \%$ \\
\hline Uses interest on overdue payment as a way to speed up payments from customers & 0 & $0 \%$ \\
\hline Deliberately delays payments of value added & 0 & $0 \%$ \\
\hline Raises capital from a factoring company & 0 & $0 \%$ \\
\hline Has obtained some kind of subsidy & 0 & $0 \%$ \\
\hline
\end{tabular}

Table 1 depicts the responses from the highest application to the lowest application of the different variety of financial bootstrapping techniques used by new micro-enterprises in the retail sector. The six most widely used bootstrapping methods are (1) withhold owners salaries (2) share premises with others (2) withhold owners salaries (3) buy on consignment (4) minimise inventory (5) Seek out the best conditions possible with suppliers, and (6) Deliberately delay payments to suppliers

The six least used methods are (1) has obtained some kind of government subsidy (2) raise capital from a factor (3) deliberately delay payment of value added (4) use interest on overdue payment as a way to speed up payments from customers (5) lease equipment from leasing businesses (6) share employees with other businesses.

\subsection{Principal component analysis}

According to Leech et al. (2005) the principal components analysis is a data reduction technique used to reduce a large number of variables to a smaller set of underlying factors that summarize the essential information contained in the variables. The decision about which principal components to retain depends on the percentage of the variance accounted for the variable, the absolute variance accounted for by each principal component and whether the component can be meaningfully interpreted. Principal components with Eigen values greater than one are usually retained. In addition as pointed out by Winborg and Landstrom (2001), although variables for factor analysis are generally assumed, to be metric variables, dummy variables (coded 0 or 1 ) can be used along with metric variables. The departures from the assumption of normality involved in the use of non-metric variables, apply only to the extent that the observed 
correlations between variables can diminish.

Table 2: Rotated component matrix

\begin{tabular}{|c|c|c|c|c|}
\hline & 1 & 2 & 3 & 4 \\
\hline Obtain loans from family and friends & 0.809 & & & \\
\hline Withhold all or part of owner's payment & 0.777 & & & \\
\hline Use owners credit card for business expense & 0.725 & & & \\
\hline Contribute capital via other projects the owners get paid for & 0.696 & & & \\
\hline Employ relatives and friends at non-market rate & 0.601 & & & \\
\hline Buy on consignment from suppliers & & 0.808 & & \\
\hline Seek out best conditions with suppliers & & 0.726 & & \\
\hline Deliberately delay payment to suppliers & & 0.677 & & \\
\hline Deliberately choose customers who pay quickly & & 0.619 & & \\
\hline Get payment in advance from customers & & 0572 & & \\
\hline Offer customer discount to pay early & & 0.541 & & \\
\hline On occasion liquidated a business relationship with a customer for frequently paying late & & 0.503 & & \\
\hline Give same terms of payments to all customers & & 0.477 & & \\
\hline Use routine to speed up invoicing & & 0.421 & & \\
\hline Share premises with other & & & 0.803 & \\
\hline Buy used equipment instead of new & & & 0.777 & \\
\hline Share equipment with other businesses & & & 0.721 & \\
\hline Borrow equipment or machinery from other businesses & & & 0.672 & \\
\hline Deliberately delay payments to suppliers & & & & 0.811 \\
\hline Use different routines for minimising capital invested in stock & & & & 0.745 \\
\hline Occasionally hires personnel for a shorter period instead of employing permanently & & & & 0.692 \\
\hline Eigen value & 24.409 & 7.207 & 5.107 & 2.779 \\
\hline$\%$ of variance explained & 45.422 & 18.766 & 11.007 & 6.349 \\
\hline Cronbach's alpha & 0.803 & 0.761 & 0.753 & 0.777 \\
\hline
\end{tabular}

Item loading of less than 0.300 removed

Table 2 shows that five components with Eigen values greater than one account for $81.54 \%$ of the total variance. Factor one is titled owners resources and consists of five items. These resources include those from the owner of the business directly and those that are close to the owners such as family and friends. Access to formal finance is limited for new entrepreneurs and networking with family and friends is often one of the major ways of securing capital. Bhaird and Lucy (2008) and Mwarari (2013) note that new SMMEs often depend on loans from family and friends for seed and other early stage investments.

Factor 2 is titled management of accounts receivable. The factor consists of nine items. The items include to seek out best conditions with suppliers and to buy on consignment from suppliers. This factor shows the importance of trade credit to immigrant entrepreneurs. Wilson and Summers (2002) point out that SMMEs often find access to bank loans difficult. Berger and Udell (2006) argue that since only a limited number of SMMEs have access to loans from financial institutions, trade credit may often be the best or only available source of external funding for working capital. Trade credit is a substitute to bank credit for firms that are credit-rationed by banks. Factor 3 is titled sharing resources. By sharing resources, immigrant entrepreneurs can save on cost. Miller et al. (2008) point out that for a business owner, linked to the concept of social networking is the concept of business strategy. This means collaborative conduct driven by the need to achieve firm success. Factor 4 is titled delaying payment. This can help to improve the cash flow of entrepreneurs. However, delaying payment can impact negatively on the reputation of an entrepreneur.

\section{Conclusions}

New micro-enterprises in the retail sector are important to the reduction of unemployment, poverty and income equality in South Africa. The failure rate of new micro-enterprises in the retail sector is very high in South Africa. Access to formal finance is one of the primary causes of failure. New micro-enterprises find it very difficult to access conventional debt and equity markets. Thus, innovative approaches to obtain resources (bootstrapping) are needed for new micro-enterprises in the retail sector to survive and grow. This study investigates the financial bootstrapping methods used by new micro- 
enterprises in the retail sector in South Africa. Bootstrapping is the use of resourceful and innovative methods, which (i) minimize the amount of finance firms need to raise through financial market transactions with traditional outside financiers and (ii) allow firms to secure resources owned by others at little or no cost. Factor analysis identified four bootstrapping methods used by new micro- enterprises in the retail sector. The methods are owners' resources, management of accounts receivable, sharing resources and delaying payment.

\section{Recommendations}

Government agencies such as the Small Enterprise Development Agency (SEDA), the Small Enterprise Finance Agency (SEFA) should strive to create awareness of bootstrapping strategies that owners of new micro-enterprises in the retail sector can use. Training on improving access to finance should not only focus on how entrepreneurs can obtain external debt and equity but on how new entrepreneurs can develop an entrepreneurial approach to resources through an understanding of bootstrapping strategies. Thus, education and training of the owners of new micro-enterprises in the retail sector on the various bootstrapping techniques can be critical to the development of new micro enterprises. SEDA should have field agents that will constantly visit the owners of new micro enterprises to educate them on bootstrapping strategies. The use of government guarantees by the owners of new micro- enterprises in the retail sector is extremely limited. The existence of government guarantee programmes should be better publicised to create awareness for these programmes. Universities should make it part of their community engagement to visit the owners of new microenterprises in the retail sector and train the owners on bootstrapping strategies. It is also important for the owners of new micro-enterprises to be proactive and understand the various types of bootstrapping strategies that can be employed.

\section{References}

Adcorp. (2012). New Business Start-ups Slump to Alltime Low. [Online] Availablehttp://www.adcorp.co.za/NEws/Pages /Newbusinessstart-upsslumptoall-timelow.aspx (September 22, 2013).

Arko-Achemfuor, A. (2012). Financing Small, Medium and Micro Enterprises (SMMEs) in Rural South Africa: An Exploratory Study of Stokvels in the Nailed Local Municipality, North West Province. Journal of Social Anthropology, 3(2), 127-33.

Atieno, R. (2009). Linkages, access to finance and the performance of small-scale enterprises in Kenya. Journal of Accounting and Business Research, 3(1), 33-48.

Baker, T., \& Nelson, R.E. (2005). Creating Something from Nothing: Resource Construction through Entrepreneurial Bricolage. Administrative Science Quarterly, 50, 329-366.

Barringer, B., \& Ireland, R. (2010). Entrepreneurship: successfully launching new ventures. (4th ed.). New Jersey: Pearson Education.

Beck, T. (2007). Financing constraints of SMEs in developing countries: evidence, determinants and solutions. Journal of International Money and Finance, 31(2), 401-441.

Berger, A., \& Udell, G. (2006). A more conceptual framework for SME financing. Journal of Banking and Finance, 30(11), 2945-2966.

Bhaird, C.M., \& Lucy, B. (2008). Determinants of capital structure in Irish SMEs. Small Business Economics, 4(2), 310-326.

Blumberg, B.F., \& Letterie, W.A (2008). Business starters and credit rationing in small business. Small Business Economics, 3(1), 187200.

Bolingtoft, A., Ulhoi, J.P. Madsen., A.H \& Neergaard, H. (2003). Effect of financial factors on the performance of new venture companies in high tech and knowledge-intensive industries: an empirical study in Denmark. International Journal of Management, 20(1), 535-547.

Brush, C.G (2008). Pioneering Strategies for Entrepreneurial Success. Business Horizons, 51(1): 21-27

Carpenter, R.E., \& Petersen, B.C (2002). Is the growth of small firm constrained by internal equity? The Review of Economics and Statistics, 84(2), 298-309.

Cooper, D.R., \& Schindler, P.S, (2008). Business Research Methods. (12th ed.). New York: McGraw Hill Inc.

Cornwall, J. (2010). Bootstrapping. (1st ed.). New Jersey: Pearson Education.

Demirguc-Kunt, A., Maksimovic, V., Beck, T., \& Laeven, L. (2006). The determinants of financing obstacles. International Journal of Money and Finance, 25(6), 932-952.

Ebben, J., \& Johnson, A. (2006). Bootstrapping in small firms: An empirical analysis of change over time. Journal of Business Venturing, 21(1), 851-865.

Elsenhardt, K.M., \& Martin, J.A (2000). Dynamic capabilities: what are they? Strategic Management Journal, 21(1), 1105-1121.

Farrington, Shelley, Matchaba-Hove, Tony, (2011). The Influence of Entrepreneurial Orientation on Small Business Success.[Online] Available: http:// www.saims2011.ukzn.ac.za/Libraries/Final_ Programe/Final_SAIMS_Programme_2011.sflb.ashx (September 15, 2013).

Fatoki, O. (2013). An investigation into the financial bootstrapping methods used by immigrant entrepreneurs in South Africa. Journal of Economics, 4(2): 89-96

FinMark Trust. (2006). Fin scope small business survey report.[Online] Available: http://www.finmarktrust.org.za ( May 18, 2013).

Gauteng Province Provincial Treasury (2012). The retail industry on the rise in South Africa [Online] Available: http://www.treasury.gpg.gov.za/Document/Documents/QB1\%20The\%20Retail\%20Industry\%20on\%20the\%20Rise.pdf (October 
10, 2013).

Gitman, L.J. (2003). The Principles of Managerial Finance.(11 th ed.) New York: Pearson Education Inc.

Gree, A, \& Thurnik, C. (2003). Firm selection and industry evolution: the post country performance of new firm. Journal of Evolutionary Economics, 4 (4), 243-264.

Herrington, Mike, Kew, Jacque, Kew, Penny, (2009). Global Entrepreneurship Monitor, South African report.[Online] Available: http://www.gbs.nct.ac.za/gbswebb/userfiles/gemsouthafrica2000pdf April 15, 2013).

Jensen, M. C., \& Meckling, W.H. (1976). Theory of the firm: managerial behaviour, agency cost and ownership structure. Journal of Financial Economics, 3(4), 305-360.

Kon, Y. Storey, D.J (2003). A Theory of Discouraged Borrowers. Small Business Economics, 21(1), 37-49.

Kraaijenbrink, J., Spender, J.C., \& Groen, A.J. (2010). The Resource-Based View: A Review and Assessment of its Critiques, Journal of Management, 36(1), 349-372.

Lahm, R.J., \& Little, H.T. (2005). Bootstrapping business start-ups: foundership literature, textbooks, and teaching practices versus current business practices? Journal of Foundership Education, 8, 61-73.

Leech, N.L., Barrett, K.C., \& Morgan, G.A (2005). SPSS for intermediate statistics, use and interpretation. (2nd ed.). Lawrence Erlbaum Associates Inc, New Jersey.

Maas, Gideon, \& Herrington, Mike. (2006). Global entrepreneurship monitor South African report. [Online] Available: http://www.gemconsortium.org/document.aspx?id756 (September 6, 2013).

Miller, N.J., Besser, T. \&, Malshe, A. (2008). Strategic Networking among Small Businesses in Small US Communities. International Small Business Journal, 25 (6), 631-665.

Ntema, John, \& Marais, Lochner, (2012). The role of the informal retail business sector in economic development the case of Mangaung township Bloemfontein. [Online] Available: http://www.csbd.co.za/presentations.html. (October 18, 2013).

Mwarari, M.M (2013). Factors influencing listings of Kenyan SMEs in the securities market for capital raising opportunities. European journal of Management Sciences and Economics, 1(2), 99-115.

Myers, S.C (1984). Capital structure puzzle. Journal of Finance, 39(3), 575-592.

Parliament of the Republic of South Africa. (2005). The White Paper on National Strategy for the development of small business. [Online] Available: http://www.info.gov.za/whitepaper/1995/smallbus.htm (September 17, 2013).

Pfeffer, J., \& Salancik, G.R (1978). The External Control of Organizations: A Resource Dependence Perspective. New York: Harper and Row,

Roberts, B. (2003). Bootstrapping is back: Entrepreneurs dig deep and make personal sacrifices for their businesses. Electronic Business, (29), 44-45.

Rolfe, Robert, Woodward, Douglas, Ligthelm, Andre \& Guimaraes, Paulo, (2010). The Viability of Informal Micro-enterprise in South Africa. [Online]: Available: http://whitman.syr.edu/ABP/Conference/Papers/The\%20Viability\%20of\%20Informal\%20MicroEnterprise\%20in\%20South\%20Africa.pdf (September 18, 2013).

Rogerson, C.M. (2008).Tracking SMME development in South Africa: issues of finance, training and regulatory environment. Urban Forum, 19, 61-81.

Van Scheers, L (2010). Challenges of small family groceries shops in South Africa. World Journal of Entrepreneurship, Management and Sustainable Development, 6(3), 221 - 231

Schinck, Anabela, Sarkar, Soumodip, (2012). Financial Bootstrapping: a critical entrepreneurship skill, CEFAGE-UE Working Paper 2012/20.

http://www.cefage.uevora.pt/en/producao_cientifica/working_papers_serie_cefage_ue/financial_bootstrapping_a_critical_entrepr eneurship_skill (April 15, 2013).

South African Venture Capital Association. (2008). Venture capital funding. [Online] Available: http://www.savca.co.za/kpmgsurvey /default.aspn (October 20, 2013).

Statistics South Africa. (2013). Quarterly labour force survey. [Online] Available: http://www.statssa.gov.za/publication/find publication asp (September 18, 2013).

Stiglitz, J., \& Weiss, A. (1981). Credit rationing in markets with imperfect information. American Economic Review, 71(3), 393-410.

Timmons, JA, Spinelli, S, (2007). New venture creation: entrepreneurship for the $21^{\text {st }}$ century. McGraw Hill, Boston.

Tomory, E.M (2011). Bootstrap financing: four case studies of technology companies. International Journal of Management Cases, 13(3), 531-538.

Vanacker, T., Mamigart, S., Meuleman, M., Sel, L., (2011). The Impact of Financial Bootstrap Strategies on Value Added in New

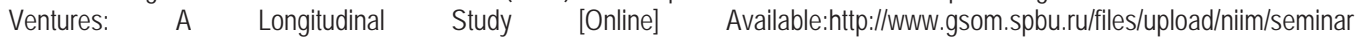
Isophie_manigart_bootstrap_strategies (May 14, 2013).

Von Broembsen, Marlese, Wood, Eric, \& Herrington, Mike, 2005. Global entrepreneurship monitor South Africa report. http://www.gsb.uct.ac.za/gsbwebb/userfiles/gem2005.pdf [Online] Available: (September 19, 2013).

Wilson, N. \& Summers, B. (2002). Trade credit terms offered by small firms: Survey evidence and empirical analysis. Journal of Business Venturing and Accounting, 29(3), 317-351.

Winborg, J. (2008). Use of financial bootstrapping in new businesses: a question of last resort? Venture Capital, 11(1), 71-83.

Winborg, J., \& Landstrom, H. (2001). Financial Bootstrapping in Small Businesses: Examining Small Business Managers' Resource Acquisition Behaviors. Journal of Business Venturing, 16, 235-254.

Winton, A., \& Yerramilli, V. (2008). Entrepreneurial finance: banks versus venture capital. Journal of Financial Economics, 88 (1), $51-79$. 
Wong, P.K., Ho, Y.P., \& Autio, E, (2005). Entrepreneurship, innovation and economic growth: Evidence from GEM data. Small Business Economics, 24(3), 335-350.

Yilmazer, T., \& Schrank, H. (2006). Financial intermingling in small family businesses. Journal of Business Venturing, $21,726-751$.

Zhou, Huan, \& Chen, Xiaoyun, (2008). Resource capabilities and new venture choice. [Online] Available: http://74.125.77.132/search?q =cache:mgr4d29qtqpQ5:www.ceauk.org.uk/20 (May 25, 2013). 